\title{
Sådan publicerer du html-filer, der indeholder billeder, i OJS 3
} til 0JS 3.2 i årgang 12 nummer 11.

- Når du linker til et billede i din html-fil, skal du blot anføre navnet på din billedfil, inkl. filformat: <img src="filename.jpg">

- Herefter uploader du html-filen, og når den ligger placeret som publiceringsklar fil under 'Publiceringsversioner' på produktionssiden, klikker du på den lille blå pil og vælger 'Rediger'

Publiceringsversioner

(

Redigér Erstat fil Slet
Tilføj publiceringsversion

- Her får du mulighed for at hente dine billeder ind, én ad gangen:

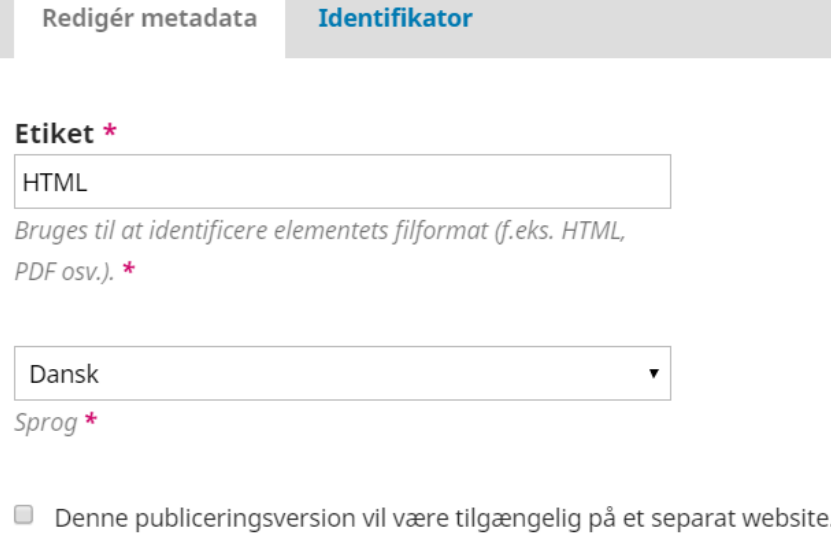

Denne publiceringsversion vil være tilgængelig på et separat website. 
- Efter at have klikket på 'Upload fil' fremkommer følgende valgmulighed, hvor du vælger 'Billede':

Upload en relateret fil

$\begin{array}{lll}\text { 1. Upload fil } & \text { 2. Gennemse oplysninger } \quad \text { 3. Bekræft }\end{array}$

Artikelmateriale *

Vælg artikelelement

Vælg artikelelement

Multimedia

Billede

HTML style-sheet

Fortsæt Annuller

- Nu kan du hente dit første billede ind:

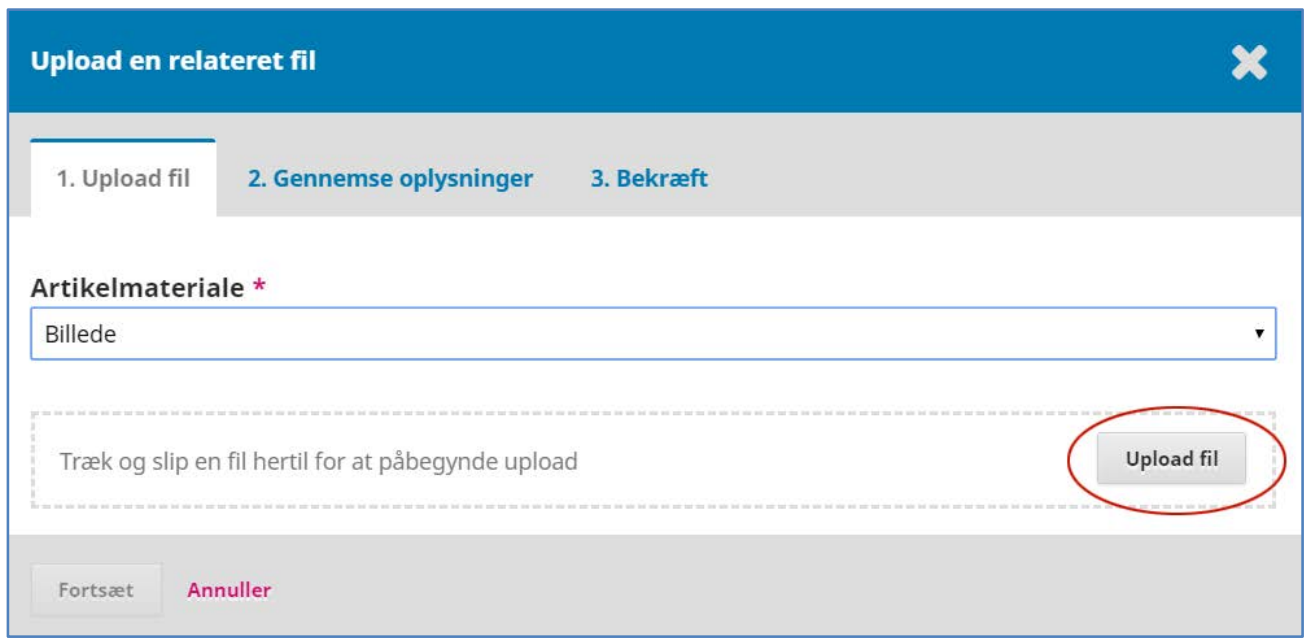

- Herefter klikker du på 'Fortsæt'

Upload en relateret fil

$\begin{array}{lll}\text { 1. Upload fil } & \text { 2. Gennemse oplysninger } \quad 3 . \text { Bekræft }\end{array}$

Artikelmateriale *

Billede

admin, indsendelse.png

Skift fil 
- Du får nu mulighed for at tilknytte informationer til billedfilen. Dette er ikke påkrævet.

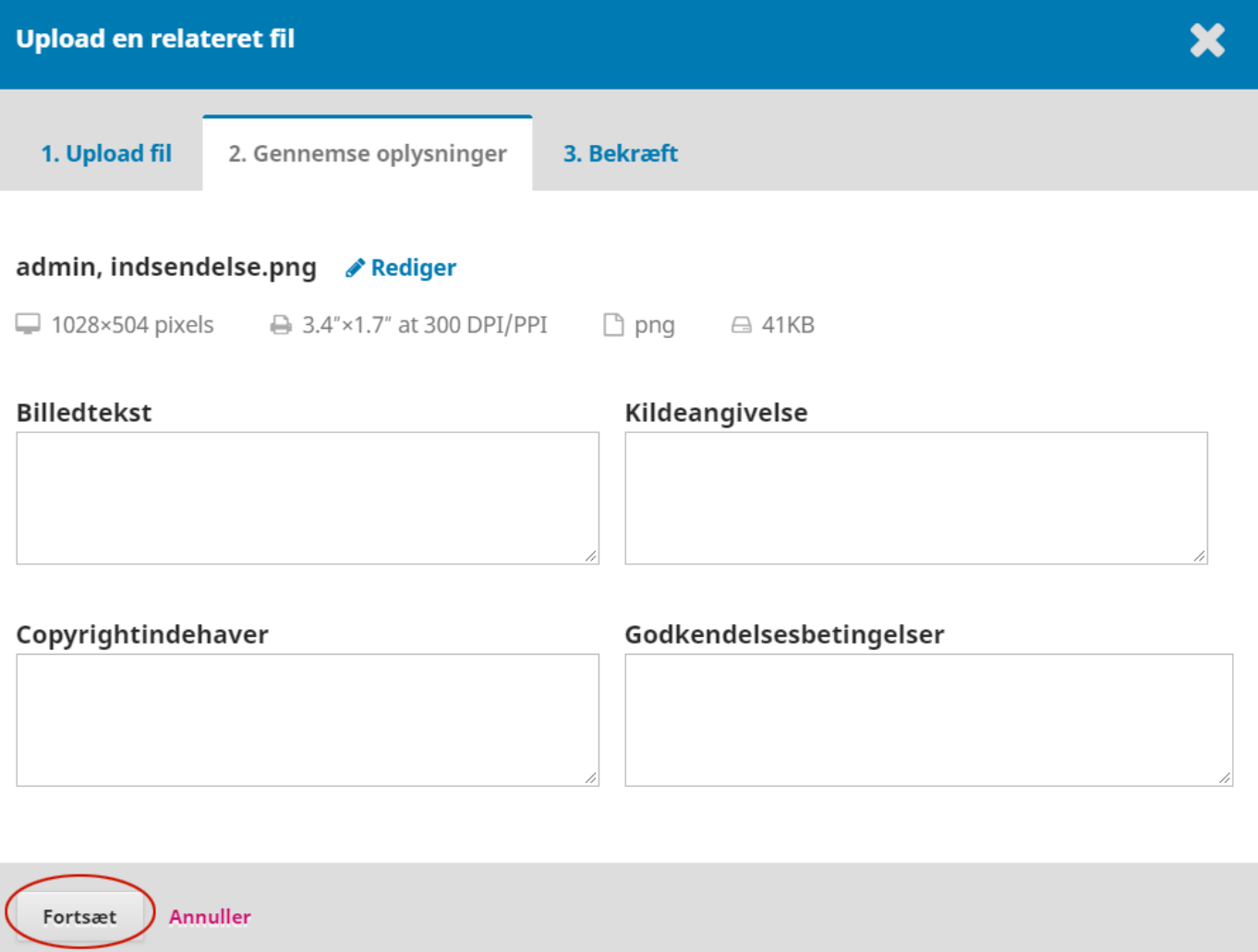

- Efter evt. at have udfyldt diverse felter og klikket på 'Fortsæt', er du nået frem til afslutningen. Klik på 'Udfør'.

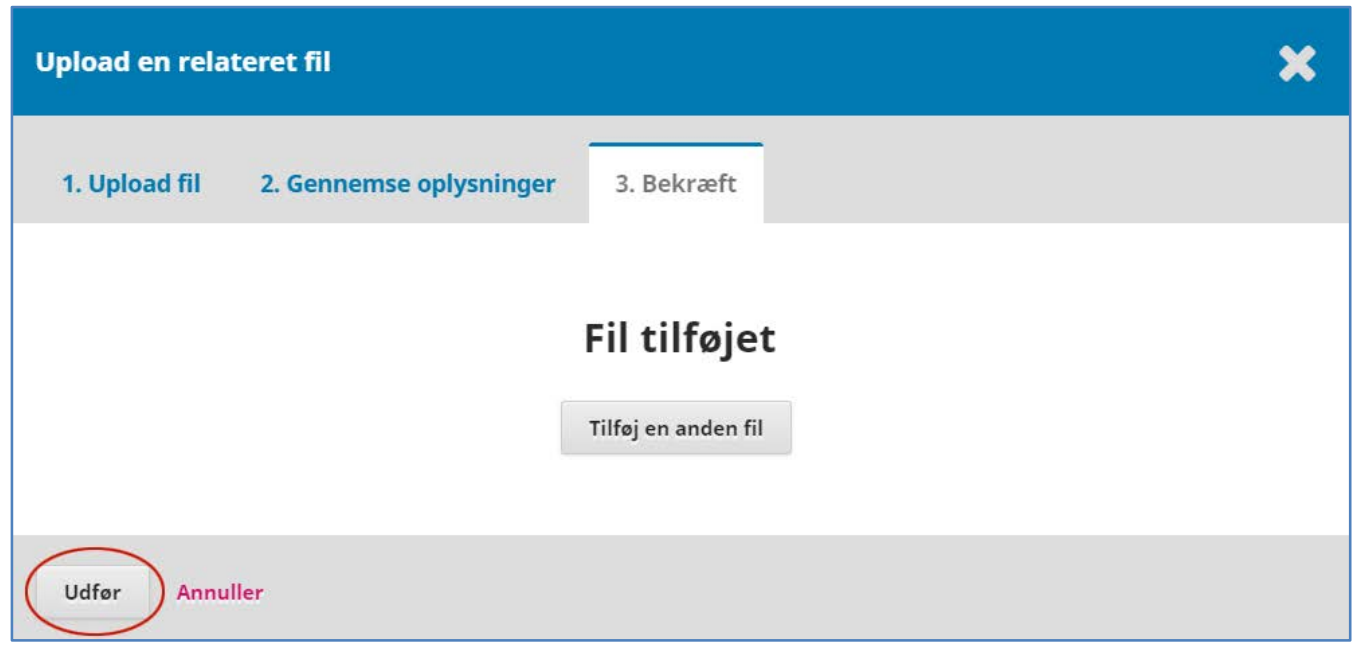

Har du flere billeder, der linkes til i dit html-dokument, gentager du blot processen ved at vælge knappen 'Tilføj en anden fil'. 